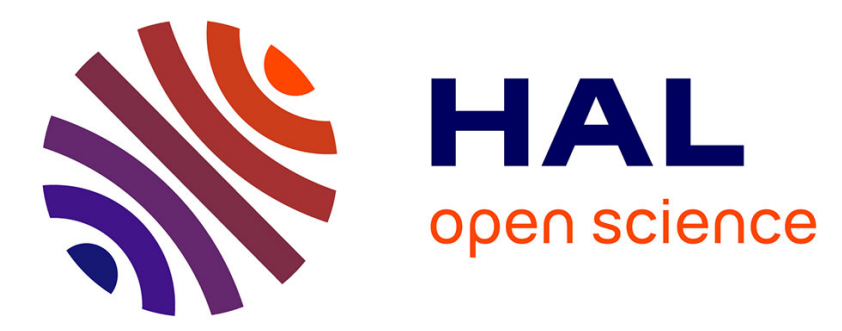

\title{
Chemical-Physical Characterization and in vitro Preliminary Biological Assessment of Hyaluronic Acid Benzyl Ester-Hydroxyapatite Composite
}

\author{
C. Giordano, V. Sanginario, L. Ambrosio, L. Di Silvio, M. Santin
}

\section{- To cite this version:}

C. Giordano, V. Sanginario, L. Ambrosio, L. Di Silvio, M. Santin. Chemical-Physical Characterization and in vitro Preliminary Biological Assessment of Hyaluronic Acid Benzyl Ester-Hydroxyapatite Composite. Journal of Biomaterials Applications, 2006, 20 (3), pp.237-252. 10.1177/0885328206051811. hal-00570763

\section{HAL Id: hal-00570763 \\ https://hal.science/hal-00570763}

Submitted on 1 Mar 2011

HAL is a multi-disciplinary open access archive for the deposit and dissemination of scientific research documents, whether they are published or not. The documents may come from teaching and research institutions in France or abroad, or from public or private research centers.
L'archive ouverte pluridisciplinaire HAL, est destinée au dépôt et à la diffusion de documents scientifiques de niveau recherche, publiés ou non, émanant des établissements d'enseignement et de recherche français ou étrangers, des laboratoires publics ou privés. 


\title{
Chemical-Physical Characterization and in vitro Preliminary Biological Assessment of Hyaluronic Acid Benzyl Ester-Hydroxyapatite Composite
}

\author{
C. GIORDANO* \\ Department of Chemistry, Materials \\ and Chemical Engineering 'Giulio Natta' \\ Polytechnic of Milan \\ Via L. Mancinelli 7-20131 Milan, Italy \\ V. SANGINARIO AND L. AMBROSIO \\ Institute of Composite and Biomedical Materials \\ IMCB-CNR, Piazzale Tecchio 80 \\ 80125 Naples, Italy \\ L. Di Silvio \\ Guy's, King's and St Thomas' Medical and Dental Institute \\ King's College London, Biomaterials Science \\ Guy's Hospital, St Thomas' Street \\ London SE1 9RT, UK \\ M. SANTIN \\ School of Pharmacy \& Biomolecular Sciences \\ University of Brighton, Cockcroft Building \\ Lewes Road, Brighton BN2 4GJ, UK
}

*Author to whom correspondence should be addressed. E-mail: carmen.giordano@polimi.it 


\begin{abstract}
HYAFF ${ }^{\circledR} 11$ is a biocompatible, biodegradable benzyl ester of hyaluronic acid. However, in order to use it for orthopedic application, its mechanical performance needs to be improved. In this study, a novel composite based on $\mathrm{HYAFF}^{\circledR} 11$ polymer matrix reinforced with hydroxylapatite (HA) has been developed. Its advantage is having a similar component of the mineral phase of bone resulting in favorable osteoconductive properties. The present study has examined the compressive mechanical and surface chemical-physical properties of the novel HYAFF ${ }^{\circledR} 11-\mathrm{HA}$ composite. Preliminary biological investigations, including $\mathrm{pH}$ and cytotoxicity studies of the material extracts, have also been performed using an in vitro primary human osteoblast-like cell model. Moreover, protein, especially fibronectin adsorption has been investigated following incubation in culture medium and human plasma. The results show a grainy surface topography composed mainly of $\mathrm{C}, \mathrm{P}$, and $\mathrm{Ca}$, with a $\mathrm{Ca} / \mathrm{P}$ atomic ratio indicating $\mathrm{HA}$ on the composite surface. Mechanical analysis shows an improvement of the compressive properties of HYAFF11 matrix, both in the dry and swollen states, with values in the range of that of spongy bone. No cytotoxic effects and no inhibition of cell proliferation have been observed in the presence of the material extracts with $\mathrm{pH}$ values within acceptable ranges for cell vitality. Protein studies reveal a similar pattern, but a higher amount of fibronectin following incubation in human plasma when compared with culture medium. The results show that the novel $\mathrm{HYAFF}^{\circledR} 11-\mathrm{HA}$ composite shows a great potential for application in orthopedic fields, especially as vertebral trabecular bone substitute.
\end{abstract}

KEY WORDS: hydrogel, composite, surface analysis, stress analysis, cell response, protein adsorption, biocompatibility, osteoblast, in vitro tests, cell culture.

\title{
INTRODUCTION
}

$\mathbf{M}$ usculoskeletal conditions are becoming an increasing health concern in aging population. Common treatments in fracture repair and total joint replacement still use traditional methods, such as autograft and allograft for bone repair, both of which have limitations.

The most commonly used biomaterials for orthopedic applications are natural and modified natural materials, as well as metals, ceramics, and synthetic polymers. In order to achieve specific properties not attainable by single-phase materials, it is now possible to design composites combining polymers, ceramics, and metals in order to obtain tailor-made devices for applications in various biomedical fields. Synthetic polymeric composites are very attractive biomaterials because of their similarities with most of the structural living tissue, composed of macromolecular composites.

Owing to their biodegradability, high biocompatibility, and nontoxicity, many natural polysaccharides have more recently been used for biomedical applications. Particular attention has been given to the 
largest glycosaminoglycans (GAG), hyaluronic acid or hyaluronan, a linear anionic polysaccharide composed of repeating disaccharide units of glucuronic acid and $N$-acetyl-glucosamine with the following molecular structure: -[D-glucuronic acid (1- $\beta$-3) $N$-acetyl-D-glucosamine $(1-\beta-4)]_{n}-[1]$. Hyaluronic acid is heterogeneously distributed in various tissues, where it plays diverse roles with regard to structural, rheological, physiological, and biological functions in the body. Physical and biological characteristics of hyaluronan in its purified form, such as water solubility, rapid resorption rate, and short half-life in the tissues, limit its possible biomedical applications. As a result, several attempts have been made to modify the molecular structure of high molecular weight purified hyaluronan in order to obtain a more stable solid material, preserving its biocompatibility and noninflammatory properties [2].

$\mathrm{HYAFF}^{\circledR}$ is a class of hyaluronan derivative polymer obtained by esterifying the free carboxyl group of glucuronic acid, with different types of alcohol (aliphatic, aryliphatic, cycloaliphatic, and others) in order to reduce the hydrophilic, negatively charged, carboxyl groups of the polyanionic polysaccharide, thereby increasing its hydrophobic components. This results in a decrease in solubility and a slight increase in structural rigidity of the macromolecule, caused by the interaction of hydrophobic group organized in hydrophobic patches. The benzyl ester of hyaluronan, termed $\mathrm{HYAFF}^{\circledR} 11$, is a well-characterized $\mathrm{HYAFF}^{\circledR}$ polymer from both the chemical-physical and biological point of view [3]. The structure of $\mathrm{HYAFF}^{\circledR} 11$ is characterized by the presence of numerous hydrophobic benzyl groups along the polymeric chain, probably organized in hydrophobic patches. This gives the molecule a more rigid and less mobile conformation, reducing its ability to interact freely with water.

In order to improve the mechanical performance of $\mathrm{HYAFF}^{\circledR} 11$, a novel composite adopting calcium hydroxyapatite, $\mathrm{Ca}_{10}\left(\mathrm{PO}_{4}\right)_{6}(\mathrm{OH})_{2}$, (HA) as reinforcement was designed. It is highly biocompatible and shows good bioaffinity by stimulating osteoconduction along its surface and being slowly replaced by host bone post implantation [4-6].

The aim of this study is to develop and characterize this novel composite based on $\mathrm{HYAFF}^{\circledR} 11-\mathrm{HA} 14 / 86(\mathrm{w} / \mathrm{w})$. Mechanical performance of the material with compressive tests in dry and wet conditions was evaluated. Surface chemical-physical properties, especially topography and stoichiometry composition, were also analyzed.

A preliminary biological examination was also performed to analyze the $\mathrm{pH}$ values and the cytotoxicity of the composite extracts after long-term incubation in culture medium. In addition, protein, especially 
fibronectin adsorption were investigated following incubations in culture medium containing fetal calf serum (FCS) and in human plasma, in order to simulate an in vivo environment.

\section{MATERIALS AND METHODS}

\section{Materials}

The composites used in this study were obtained using the fully benzylated ester of hyaluronic acid $\left(\mathrm{HYAFF}^{\circledR} 11\right.$, HATBA, batch 0.100 .00 , average Mw: 200,000 Da; Fidia Advanced Biopolymers (FAB), Albano Terme, Italy) reinforced with $86 \%(\mathrm{w} / \mathrm{w})$ ratio of HA (batch N1904, particle diameter: 2-10 $\mu \mathrm{m}$; P205 grade from IRC in Biomedical MaterialQMW, London, UK).

A solution of $8 \%(\mathrm{w} / \mathrm{w}) \mathrm{HYAFF}^{\circledR} 11$ in dimethylsulfoxide (DMSO, Sigma-Aldrich) was prepared under a slow magnetic stirrer at room temperature $\left(25 \pm 2^{\circ} \mathrm{C}\right)$ in a glass container. The homogeneous mixture was mixed at room temperature with $\mathrm{HA}$ in order to obtain the final composition of $\mathrm{HYAFF}^{\circledR} 11-\mathrm{HA} 14 / 86(\mathrm{w} / \mathrm{w})$ composite. The composite paste was placed in the selected shapes (discs, $14 \mathrm{~mm}$ diameter and $3 \mathrm{~mm}$ high, except for mechanical tests) and then washed with ethyl alcohol (95\%, Ashland Chemical) for 7 days, three changes a day. The samples were washed with bidistilled $\mathrm{H}_{2} \mathrm{O}$ (Carlo Erba) for 7 days, three changes a day, and then dried under air for 3 days.

$\mathrm{HYAFF}^{\circledR} 11$ alone was used as a control for compressive properties and protein analysis, and was prepared as described here.

\section{Mechanical Characterization}

All the tests were performed at least in triplicate.

\section{Compressive Properties}

Cylindrical specimens (6 $\mathrm{mm}$ diameter and $12 \mathrm{~mm}$ length) of HYAFF $^{\circledR} 11$ and HYAFF $^{\circledR} 11-\mathrm{HA}$ composite were tested (INSTRON testing machine model 4204; crosshead speed of $1 \mathrm{~mm} / \mathrm{min}$ ) according to ASTM D 695 in dry and swollen conditions.

\section{Surface Chemical-Physical Characterization}

\section{Surface Topography}

The samples were sputter coated (Emitech 500, 4 min at $20 \mathrm{~mA}$, $10^{-1} \mathrm{mBar}$ ) before examination under a Jeol JSM $5500 \mathrm{LV}$ at an accelerating voltage of $15 \mathrm{keV}$. 


\section{Surface Chemistry}

The samples were sputter coated (Emitech K550) and then analyzed by energy dispersive atomic X-ray (Philips XL 30; $\mathrm{LaB}_{6}$ filament; EDAX CDU leap detector) for elemental analysis.

\section{In vitro Biological Assays}

Thermanox (TMX) discs (Life Technology) as negative, nontoxic control and polyvinylchloride (PVC) discs (Life Technology) as positive, toxic control were the controls used.

All the tests were performed at least in triplicate.

\section{Elution $\mathrm{pH}$ Measures}

The samples were placed into a 24-well tissue culture plate and incubated in $1 \mathrm{~mL}$ of culture medium at $37^{\circ} \mathrm{C}$ on a plate shaker. At the selected time points $(1,3,7,14,21,28,35$, and 42 days) the aqueous extracts were collected and replaced with $1 \mathrm{~mL}$ of fresh medium and the plate placed back at $37^{\circ} \mathrm{C}$. The $\mathrm{pH}$ of the eluted medium was measured using a pH meter (Corning 240) in triplicates.

\section{Elution Cytotoxicity Assays}

Primary human osteoblast-like cells (HOBs) were isolated from trabecular bone using a previously described method [7]. Briefly, the bone chips were cultured under sterile conditions until 'osteoid seams' were seen, then digested using collagenase $(100 \mathrm{U} / \mathrm{mL})$ (Sigma) and trypsin $(300 \mathrm{U} / \mathrm{mL})$ (Sigma) solution. Following isolation, expansion, and characterization, the obtained cells were used for the cytotoxicity tests.

The sterile samples were placed into a 24 -well tissue culture plate incubated in $1 \mathrm{~mL}$ of culture medium at $37^{\circ} \mathrm{C}$ with $5 \% \mathrm{CO}_{2}$ in a humidified atmosphere. At the selected time points (1, 3, 7, 14, 21, 28 days) the aqueous extracts were collected in sterile condition, replaced with $1 \mathrm{~mL}$ of fresh medium and the plate was placed back in the incubator. One hundred microliters of $1 \times 10^{5} \mathrm{cell} / \mathrm{mL}$ cell suspension were seeded into a sterile 96-well culture plate (Beckton Dickinson) and incubated until almost confluent, usually $24 \mathrm{~h}$. The culture medium was then replaced with aqueous extract $(100 \mu \mathrm{L} /$ well $)$ and the plates were further incubated at $37^{\circ} \mathrm{C}$ with $5 \% \mathrm{CO}_{2}$ in a humidified atmosphere for 72 and $48 \mathrm{~h}$. Ten microliters of MTT (Sigma) solution $(5 \mathrm{mg} / \mathrm{mL}$ in phenol- and ascorbic acid-free culture medium containing FCS) was added to each well, the plates were incubated for a further $4 \mathrm{~h}$ and then the medium was removed by inversion. One hundred microliters of DMSO (Merck) 
was added to each well and mixed for 20 min until the crystals were completely dissolved. Absorbance was measured by a Dynatech MR 700 plate reader, using a test wavelength of $570 \mathrm{~nm}$ and a reference wavelength of $630 \mathrm{~nm}$.

\section{Protein Adsorption Studies}

The sterile samples were placed in a 24-well plate, washed in PBS (Oxoid Ltd) and then equilibrated with $1 \mathrm{~mL}$ of FCS-free culture medium for $30 \mathrm{~min}$. The samples were then incubated either in a culture medium containing $10 \%$ FCS or in human plasma obtained from healthy human donor blood in static conditions at $37^{\circ} \mathrm{C}$ for $1 \mathrm{~h}$. The specimens were removed, washed carefully in $1 \mathrm{~mL}$ of PBS for $5 \mathrm{~min}$ at room temperature, placed in a new 24-well plate and proteins were eluted for $1 \mathrm{~h}$ at $37^{\circ} \mathrm{C}$ by $200 \mu \mathrm{L}$ of SDS-PAGE sample buffer: (2\% (w/v) SDS, $5 \%(\mathrm{v} / \mathrm{v}) \beta$-mercaptoethanol, 10\% (w/v) glycerol, $0.02 \%(\mathrm{w} / \mathrm{v})$ bromophenol blue in $62.5 \mathrm{mM}$ tris-HCl, $\mathrm{pH}$ 6.8). Supernatants were withdrawn and boiled for $3 \mathrm{~min}$. After cooling, $20 \mu \mathrm{L}$ of each elutions were analyzed by a 10\% SDS-PAGE electrophoresis using a Bio-Rad Miniprotean II Module. Electrophoresis was performed at $100 \mathrm{~V}, 46 \mathrm{~mA}$ for $90 \mathrm{~min}$ according to Laemmli's method [8]. As controls, 1:10 diluted complete DMEM and 1:10 diluted human plasma were also used. Protein molecular weight was evaluated by loading SDS-PAGE standard (Bio-Rad, Mw range 205,000-7600 Da: cat. 161-0318). Polyacrylamide gels were stained for $1 \mathrm{~h}$ using a Silver Stain Plus Kit (Bio-Rad). Following electrophoresis, proteins were blotted onto nitrocellulose Hybond membranes (Amersham) using a Mini Trans Blot Module (Bio-Rad). Membranes were blocked with 1\% (w/v) gelatin in PBS and incubated with $50 \mu \mathrm{g} / \mathrm{mL}$ primary antibody solution containing rabbit antibodies (Dako) against either human or bovine fibronectin (Fbn) overnight at room temperature. Goat anti-rabbit immunoglobulins conjugated with horseradish peroxidase (Dako), diluted 1:2000 in the same buffer, were used as secondary antibody. Bands were detected using $0.03 \%(\mathrm{w} / \mathrm{v})$ 3-amino-9-ethylcarbazole and $0.03 \%(w / v) \mathrm{H}_{2} \mathrm{O}_{2}$ (Sigma-Aldrich) in $0.1 \mathrm{M}$ sodium acetate (Sigma-Aldrich), $\mathrm{pH} 5.2$, as substrates.

\section{RESULTS}

\section{Mechanical Characterization}

\section{Compressive Tests}

The compressive elastic modulus $(E)$, the maximum compressive strength $\left(\sigma_{\max }\right)$ and the maximum deformation $\left(\varepsilon_{\max }\right)$ were evaluated 
for $\mathrm{HYAFF}^{\circledR} 11-\mathrm{HA}$ composite and $\mathrm{HYAFF}^{\circledR} 11$ samples in dry and swollen states (Table 1, Figure 1(a) and (b)).

The results showed an increase in the mechanical properties for the composites due to the reinforcing HA phase. For the HYAFF ${ }^{\circledR} 11$, the fracture was not detectable for the plastic behavior of the materials. The same behaviors were obtained in the swollen state. In the latter case, a decrease in the compressive properties of both $\mathrm{HYAFF}^{\circledR} 11-\mathrm{HA}$ and HYAFF11 HYAFF ${ }^{\circledR} 11$ samples were observed, mainly due to the plasticizing effect of the absorbed water. The water content at the equilibrium state of $\mathrm{HYAFF}^{\circledR} 11$ has been reported as $32 \pm 2 \%$ [9] while for the $\mathrm{HYAFF}^{\circledR} 11-\mathrm{HA}$ composite it was, $5 \pm 1 \%$ due to the presence of HA.

\section{Surface Topography}

The samples showed a rough surface consisting of spherulites $<10 \mu \mathrm{m}$ in diameter (Figure 2).

\section{Surface Chemistry}

The EDAX analysis of the sample surfaces showed the following elements $-\mathrm{Ca}, \mathrm{P}, \mathrm{C}, \mathrm{Na}$, and $\mathrm{Si}$. The $\mathrm{Ca} / \mathrm{P}$ atomic ratio value of 1.75 , obtained for the composite, was close to both the typical value of stoichiometric HA and the value obtained for the HA used for the test composite preparation. No traces of S were detected (Figure 3).

\section{pH Determination of the Eluted Media}

The results obtained showed no significant differences in the $\mathrm{pH}$ values of the elution collected, remaining approximately in the range of 7-8 from day 1 to day 42 of sample incubation in the culture medium.

\section{Elution Cytotoxicity Assay}

No evidence of cytotoxicity was observed after $48 \mathrm{~h}$ (Figure 4(a)) and $72 \mathrm{~h}$ (Figure 4(b)) of incubation with HOB cells in the presence of

Table 1. Compressive properties of HYAFF ${ }^{\circledR} 11-H A$ and $H Y A F F^{\circledR} 11$ in dry and swollen states.

\begin{tabular}{lccc}
\hline & $E(\mathrm{MPa})$ & $\sigma_{\mathrm{c}}(\mathrm{MPa})$ & $\varepsilon(\mathrm{mm} / \mathrm{mm})$ \\
\hline Material (Dry) & & & \\
HYAFF 11 & $27 \pm 5$ & - & - \\
HYAFF ${ }^{\circledR} 11-\mathrm{HA}^{(14 / 86)}$ & $340 \pm 40$ & $12 \pm 1$ & $0.24 \pm 0.01$ \\
Material (Swollen) & $10 \pm 2$ & - & - \\
HYAFF 11 & $70 \pm 4$ & $4 \pm 1$ & $0.31 \pm 0.01$ \\
\hline HYAFF & & & \\
\hline
\end{tabular}



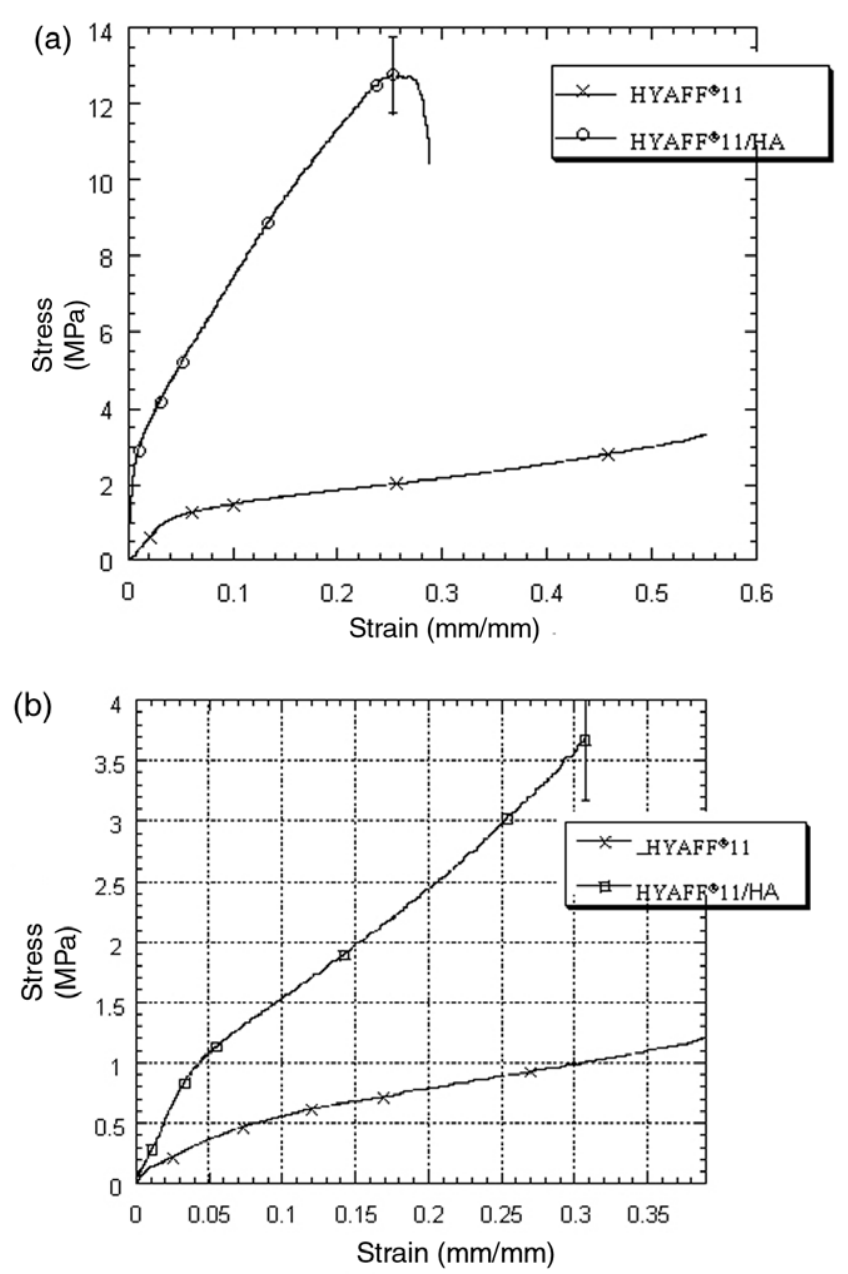

Figure 1. Compressive stress-strain curve of $\mathrm{HYAFF}^{\circledR} 11-\mathrm{HA}$ and $\mathrm{HYAFF}^{\circledR} 11$, in (a) dry and (b) swollen states.

sample extracts at the selected time points, as shown by the comparison with the TMX and PVC control extracts.

\section{Protein Adhesion}

A similar protein adsorption profile was observed following incubation of the materials in culture medium containing FCS (Figure 5(a)) and human plasma (Figure 5(b)), respectively. The SDS-PAGE for the $\mathrm{HYAFF}^{\circledR} 11-\mathrm{HA}$ specimen and the $\mathrm{HYAFF}^{\circledR} 11$ samples, incubated in human plasma showed a band with molecular weight around 


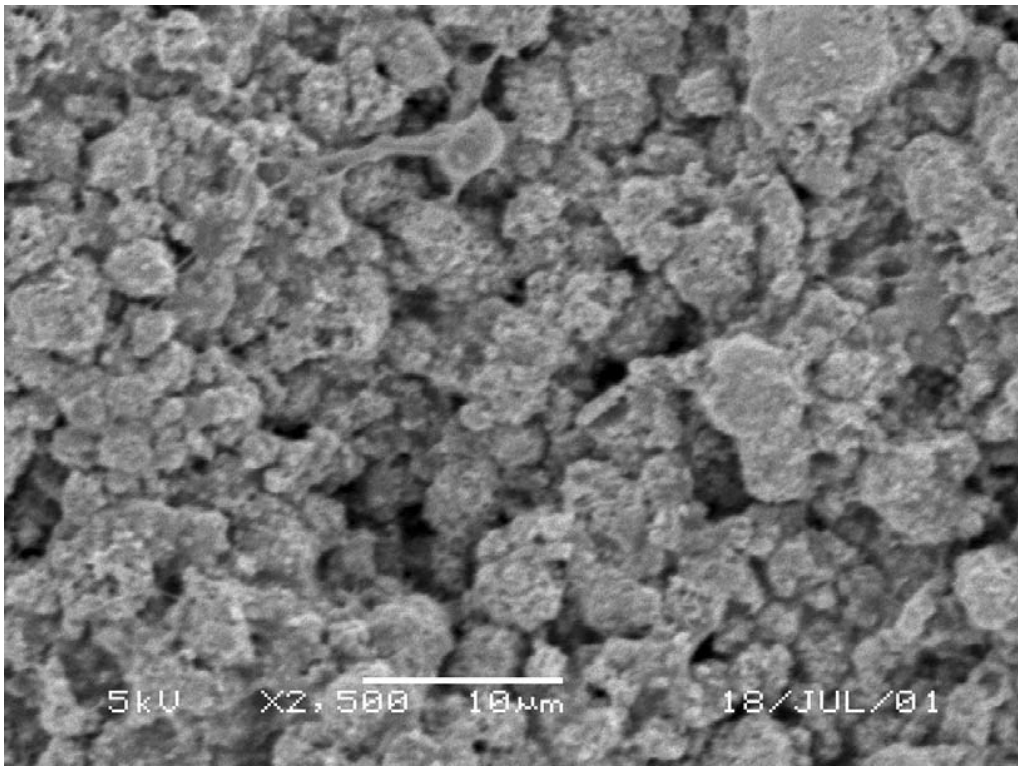

Figure 2. Scanning electron micrograph of $\mathrm{HYAFF}^{\circledR} 11-\mathrm{HA}$ composite sample surface.

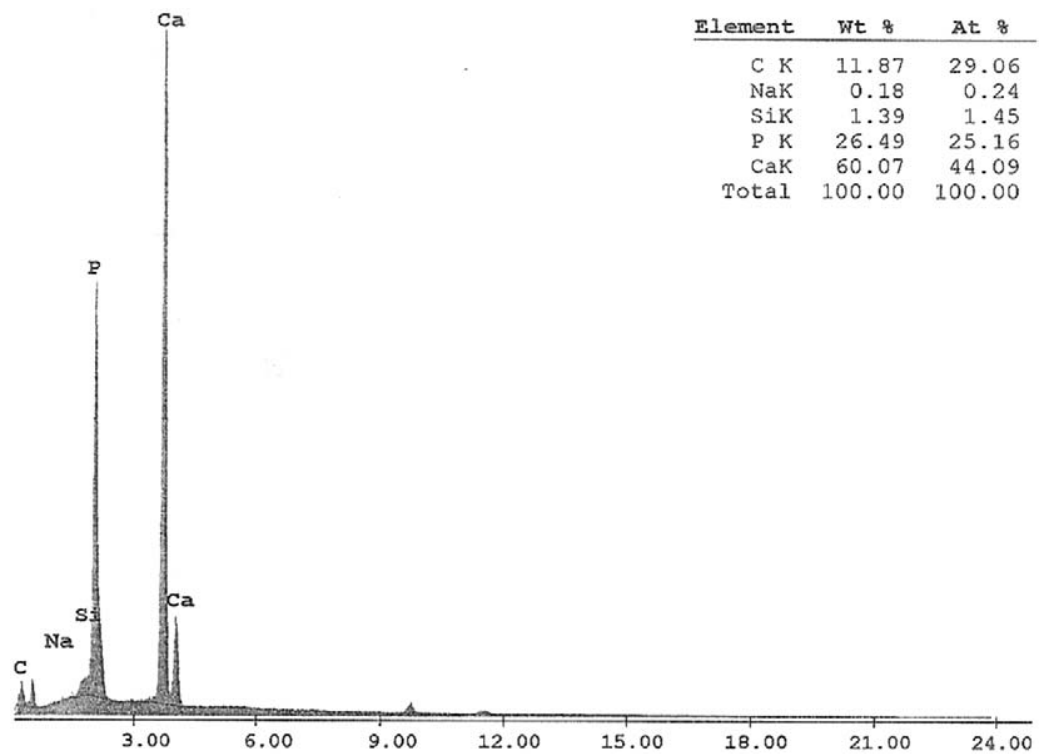

Figure 3. EDAX analysis of $\mathrm{HYAFF}^{\circledR} 11-\mathrm{HA}$ composite sample surface. 
(a) MTT $48 \mathrm{~h}$

1

1.5
1
0.5
0

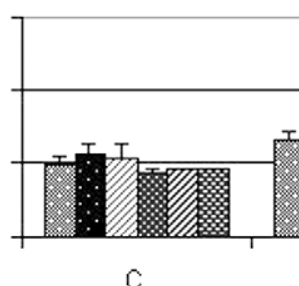

c

TMX

Dday 1

day 3

四ay 7

圆day 14

Day 21

Rday 28

Materials

(b)

MTT $72 \mathrm{~h}$

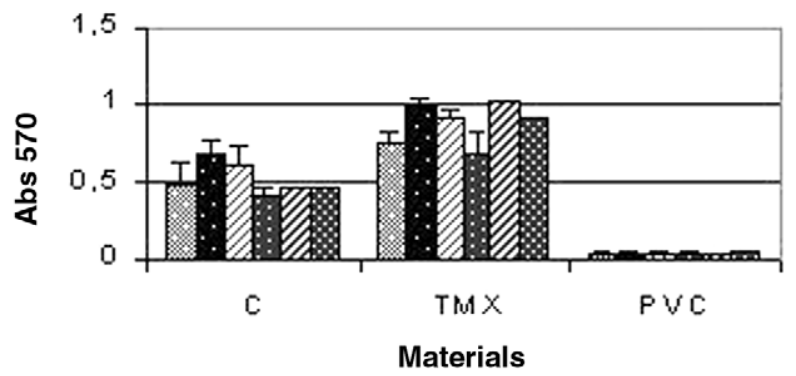

圆 day 1

ay 3

Øday 7

aday 14

Dday 21

장 day 28

Materials

Figure 4. MTT test on HOB cells cultured (a) for 48 and (b) $72 \mathrm{~h}$ in culture medium previously incubated for $1,3,7,14,21$, and 28 days with $\mathrm{HYAFF}^{\circledR} 11-\mathrm{HA}$ composite samples (C).

$205 \mathrm{kDa}$ (arrow 1) as well as protein adsorption in the range of $119-30 \mathrm{kDa}$ (indicated range) and around $7.6 \mathrm{kDa}$ (arrow 2). With the exception of the $205 \mathrm{kDa}$ band, protein adsorption was visible in the above-mentioned ranges also for materials incubated in culture medium containing FCS.

From the immunoblot analysis, fibronectin was undetectable for all the materials incubated in the culture medium containing FCS, but was clearly visible for samples incubated in human plasma (Figure 6).

\section{DISCUSSION}

In the present study, mechanical and surface chemical-physical characterization as well as a preliminary biological assessment were performed on a novel HA-reinforced hydrophilic polymer, based on $\mathrm{HYAFF}^{\circledR} 11$ polymer matrix, HYAFF ${ }^{\circledR} 11-\mathrm{HA} 14 / 86$ (w/w). 


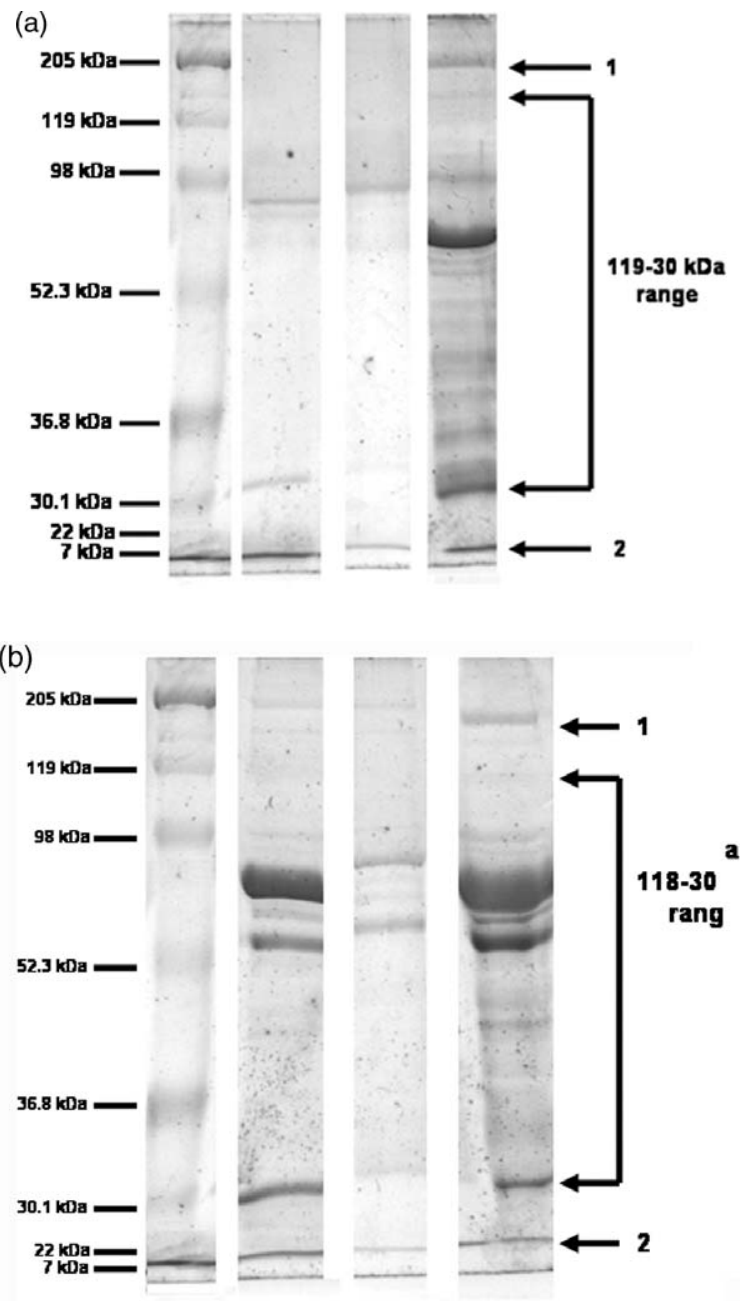

Figure 5. SDS-PAGE of samples incubated (a) in culture medium and (b) human plasma: lane 1: molecular weight standard; lane 2: $\mathrm{HYAFF}^{\mathbb{B}} 11-\mathrm{HA}$ composite; lane 3 : $\mathrm{HYAFF}^{\circledR} 11$; lane 4: relative incubation medium. Arrows and arrow range indicate protein with a different adsorption profile on the tested surfaces (for details see text).

Appropriate mechanical properties are crucial requirements in the design of bone-substitute materials. Both $\mathrm{HYAFF}^{\circledR} 11$ and $\mathrm{HA}$ are known to be bioactive, but when used alone their mechanical properties are not sufficient and hence, limit their use. Improvements in composite technology have resulted in the design of substitute materials 


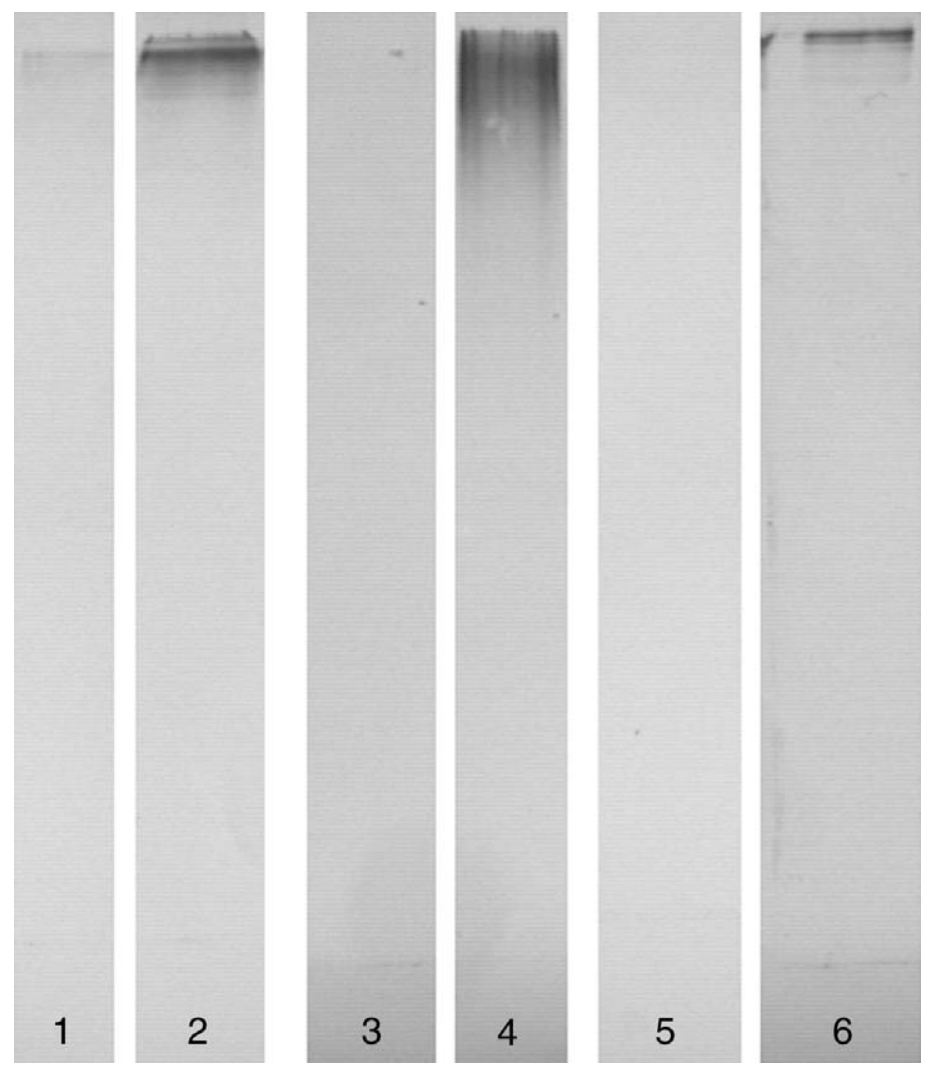

Figure 6. Immunoblot of samples incubated in culture medium (lane 1: HYAFF ${ }^{\circledR} 11-\mathrm{HA}$ composite; lane 3: HYAFF $^{\circledR} 11$; lane 5: culture medium) and human plasma (lane 2: $\mathrm{HYAFF}^{\circledR} 11-\mathrm{HA}$ composite; lane 4: $\mathrm{HYAFF}^{\circledR} 11$; line 6: human plasma).

with enhanced properties. The compressive tests have shown that it is possible to have a composite structure with compressive properties in the range of that of spongy bone. As presented in Table 1, the composite shows compressive properties in the range of vertebral trabecular bone [10]. The higher reduction of the HYAFF ${ }^{\circledR} 11-\mathrm{HA}$ compressive properties in the swollen state is due to the poor adhesion between HA and $\mathrm{HYAFF}^{\circledR} 11$, which is enhanced by the presence of water, and the presence of voids (Figure 2) generated during the preparation.

Surface topography affects important parameters involved in the cell-material interaction. Topography influences cell anchorage, orientation, alignment, and migration by recognizing surface features and 
reacting to them $[11,12]$. Rugophilia has also been described to play a role, whereby a roughened surface increases cell, especially, osteoblast response to materials $[13,14]$.

The $\mathrm{HYAFF}^{\circledR} 11-\mathrm{HA}$ composite structure showed a grainy surface with exposed HA particles, thus indicating a potentially favorable surface topography for cellular adhesion and proliferation.

In addition to topography, surface stoichiometry is another important requirement for biomaterials to promote cellular adhesion. It has been reported that exposing HA increases the osteoconductive properties with material surfaces directly in contact with cells, creating a favorable surface for enhancing osteoblast adhesion [15-21].

Surface stoichiometry analysis on the test samples showed the presence of the elements $\mathrm{C}, \mathrm{P}$, and $\mathrm{Ca}$, the expected elements in the material composition. The detected traces of $\mathrm{Na}$ and $\mathrm{Si}$ might be due to impurities related to solvents/disposables used during the specimen preparation process or to the sample holders used before/during the EDAX analysis. The absence of $\mathrm{S}$ in $\mathrm{HYAFF}^{\circledR} 11-\mathrm{HA}$ composite samples indicated that they were effectively purified from the toxic DMSO used during the composite sample preparation.

The results relating to the $\mathrm{Ca} / \mathrm{P}$ atomic ratio of the composite sample surface indicated the presence of $\mathrm{HA}$ on the surface, suggesting a composite surface microenvironment suitable for HOB cell attachment. EDAX allows the analysis of a sample surface layer that can have a maximum thickness of a few nanometers, so the described results show that the preparation method adopted, phase inversion and casting, and also the high concentration of HA used allow HA particles to be present not only in the bulk but also on the composite surface. It should be noted, however, that the values obtained from the EDAX analysis were semiquantitative. This was a result of the analysis being performed directly on the 'as-cast' sample surface, which was irregular and during the analysis, each point was not equidistant from the EDAX microscope probe. The sample surfaces were not previously treated for smoothing, thus presenting a natural surface similar to that exposed to cells once implanted in vivo.

Cellular response is known to be affected by the release of leached products as a result of the degradation process stimulated upon incubation in an aggressive environment, such as that in the human body. It has been documented in the literature that $\mathrm{pH}$ changes of the surrounding environment affect cellular activity [22,23].

The $\mathrm{pH}$ measurements of the supernatant collected for the composite for all the selected time points showed $\mathrm{pH}$ values ranging from 7 to 8 . It has been reported in literature that alkaline environment with 
$\mathrm{pH}$ values above 9 can affect cell activity [23]. It can be concluded that the reactivity of the material with the surrounding fluids was able to create a favorable microenvironment for cell viability.

Furthermore, from the cytotoxicity tests performed, there was no indication of any considerable deterioration in cell viability as assessed with the long-term eluted extracts. The results showed that there was no release of toxic leachables from the composite eluted over the selected period of time.

In order to analyze the protein pattern on the sample surface more accurately, SDS-PAGE was performed on specimens incubated both in culture medium containing FCS and, to better simulate an in vivo environment, in human plasma. The presence of fibronectin, adhesion protein signalling for HOB cells, was analyzed. Fibronectin, once adsorbed onto a material surface, has been shown to mediate and increase cell adhesion and spreading [12].

The SDS-PAGE results showed a similar pattern of protein adsorption for the test $\mathrm{HYAFF}^{\circledR} 11-\mathrm{HA}$ composite and the $\mathrm{HYAFF}^{\circledR} 11$ when incubated in culture medium. These observations imply that the cellular response of the composite should be similar to that of the $\mathrm{HYAFF}^{\circledR} 11$ control. Although the adsorption of proteins from medium supplemented with FCS was, as expected, lower than the clinically reflective incubation in plasma, the pattern of adsorption was not significantly different, suggesting a similar behavior of the composite when placed in an in vivo environment. This hypothesis is correlated by the immunoblotting of fibronectin. Fibronectin was not detected for the samples incubated in the culture medium containing FCS and for the culture medium itself, probably as a result of the dilution of FCS concentration in the culture medium to a level undetectable for Western Blot. It was however, clearly visible in those specimens incubated in human plasma.

\section{CONCLUSIONS}

Mechanical analysis showed that the presence of the HA improved the compressive properties of the $\mathrm{HYAFF}^{\circledR} 11$ matrix both in the dry and the wet states, with values in the range of that of spongy bone.

$\mathrm{HYAFF}^{\circledR} 11-\mathrm{HA} \quad 14 / 86 \quad(\mathrm{w} / \mathrm{w})$ composite sample surface analysis showed a grainy topography, the presence of $\mathrm{C}, \mathrm{P}$, and $\mathrm{Ca}$ with small traces of $\mathrm{Na}$ and $\mathrm{Si}$ impurities, and a $\mathrm{Ca} / \mathrm{P}$ atomic ratio close to the typical value of stoichiometric $\mathrm{HA}$ and to the value obtained for the HA used in sample preparation. 
The in vitro cytotoxicity tests showed no evidence of toxic leachables from the composites and acceptable $\mathrm{pH}$ values for cell survival and proliferation.

Protein adhesion analysis showed a similar protein pattern in culture medium with FCS and human plasma; with a higher amount of fibronectin detected in the latter.

In conclusion, these results indicate that the novel $\mathrm{HYAFF}^{\circledR} 11-\mathrm{HA}$ composite has potentials for a wider range of application in the field of orthopedics, especially as vertebral trabecular bone substitute.

\section{ACKNOWLEDGMENTS}

The authors wish to thank Neelam Gurav, Caroline Clifford, and Michael Kayser from Institute of Orthopaedics, UCL, London, UK and Matthew Dalby, University of Glasgow, UK, for their expertise and contribution to the present work, and the E.C. 5th FW Project: Novel Intervertebral Disc Prostheses, Contract No. G5RD-CT-2000-00267 for financial support.

\section{REFERENCES}

1. Laurent, T.C. and Fraser, J.R. (1992). Hyaluronan, FASEB J., 6(7): 2397-2404.

2. Campoccia, D., Doherty, P., Radice, M., Brun, P., Abatangelo, G. and Williams, D.F. (1998). Semisynthetic Resorbable Materials Form Hyaluronan Esterification, Biomaterials, 19: 2101-2127.

3. Iannace, S., Ambrosio, L., Nicolais, L., Rastrelli, A. and Pastorello, A. (1992). Thermomechanical Properties of Hyaluronic Acid Derived Products, J. Mater. Sci. Mater. Med., 3(1): 59-64.

4. LeGeros, R.Z. and LeGeros, J.P. (1993). Dense Hydroxyapatite, In: Hench, L.L. and Wilson, J. (eds), An Introduction to Bioceramics, Chap 9, pp. 139-180, World Scientific, Singapore.

5. Ozawa, S. and Kagusai, S. (1996). Evaluation of Implant Materials (Hydroxyapatite, Glass Ceramics, Titanium) in Rat Bone Marrow Stromal Cell Culture, Biomaterials, 17: 23-29.

6. De Groot, K., Wolke, J.G.C. and Jansen, J. (1998). Calcium Phosphate Coatings for Medical Implants, Proceeding of the Institution of Mechanical Engineering, Journal of Engineering in Medicine, 212-H: 137-147.

7. Di Silvio, L. and Gurav, N. (2001). Osteoblasts, In: Koller, M.R., Palsonn, B.O. and Masters, J.R.W. (eds), Human Cell Culture, Vol. V, Chap. 11, pp. 221-241, Kluwer Academic Publisher, UK.

8. Laemmli, U.K. (1970). Cleavage of Structural Proteins during the Assembly of the Head of Bacteriophage T4, Nature, 277: 680-685. 
9. Netti, P.A., Ambrosio, L. and Nicolais, L. (2000). Thermodynamics of Water Sorption in Hyaluronic Acid and its Derivative, In: Ottenbrite, R.M. and Kim, S.W. (eds), Polymers for Medical Applications in the Twenty First Century, Chap. 12, pp. 169-180, Tehnomics Publishing Co., Lancaster, PA, USA.

10. Morgan, E.F. and Keaveny, T.M. (2001). Dependence of Yield Strain of Human Trabecular Bone on Anatomic Site, J. of Biomechanics, 34: 569-577.

11. Curtis, A. and Wilkinson, C. (1999). New Depths in Cell Behaviour: Reactions of Cells to Nanotopography, Biochem. Soc. Symp., 65: 15-26.

12. Curtis, A.S. and Wilkinson, C.D. (1998). Reaction of Cells to Topography, J. Biomater Sci. Polym. Ed., 9: 1313-1329.

13. Harris, S.A., Enger, R.J., Riggs, B.L. and Spelsberg, T.C. (1995). Development and Characterisation of a Conditionally Immortalised Human Fetal Osteoblastic Cell Line, J. Bone Miner. Res., 10: 178-186.

14. Larsson, C., Thomsen, P., Lausmaa, J., Rodhal, M., Kasemo, B. and Ericon, LE. (1994). Bone Response to Surface Modified Titanium Implants with Different Oxide Thickness and Morphology, Biopmater, 15: 1061-1074.

15. Kasemo, B. and Lausmaa, J. (1994). Material-Tissue Interfaces: the Role of Surface Properties and Processes, Environ. Health Prospects, 102: 241-245.

16. Kasemo, B. and Lausmaa, J. (1986). Surface Science Aspects of Inorganic Biomaterials, Crit. Rev. Biocompat., 2: 335-380.

17. Stephenson, P.K., Freeman, M.A., Revell, P.A., Germain, J., Tuke, M. and Pirie, C.J. (1991). The Effect of Hydroxyapatite Coating on Ingrowth of Bone into Cavities of an Implant, J. Arthoplasty., 6: 51-58.

18. Ohgushi, H., Dohi, Y., Yoshikawa, T., Tamai, S., Tabata, S., Okunaga, K. and Shibuya, T. (1996). Osteogenic Differentiation of Cultured Marrow Stromal Stem Cells on the Surface of Bioactive Glass Ceramics, J. Biomed. Mat. Res., 32: 341-348.

19. Ohgushi, H., Dohi, Y., Yoshikawa, T., Tamai, S., Tabata, S. and Suwa, Y. (1996). In vitro Bone Formation by Rat Marrow Cell Culture, J. Biomed. Mat. Res., 32: 333-340.

20. Posner, A.S. and Betts, F. (1975). Synthetic Amorphous Calcium Phosphate and its Relation to Bone Mineral Structure, Acc. Chem. Res., 58: 273-281.

21. Dalby, M.J., Kayser, M.V., Bonfield, W. and Di Silvio, L. (2002). Initial Attachment of Osteoblasts to an Optimised HAPEX Topography, Biomaterials, 23: 681-690.

22. Davis, P.A., Huang, S.J., Nicolais, L. and Ambrosio, L. (1991). In: Szycher, M. (ed.), High Performance Biomaterials, pp. 343-368, Technomic Publishing, Lancaster, PA, USA.

23. El-Ghannam, A., Duchyne, P. and Shapiro, I. (1993). A New Bioactive Glass Template for the Synthesis Bone-like Tissue in vitro, In: Ducheyne, P. and Christiansen, D. (eds). Bioceramics 6, pp. 143-149, Butter-WorthHeinemann, Oxford. 